\title{
Century scale climate change in the central highlands of Sri Lanka
}

\author{
J De Silva and D U J Sonnadara* \\ Department of Physics, University of Colombo, Colombo, Sri Lanka. \\ *Corresponding author. e-mail: upul@phys.cmb.ac.lk
}

In this study, an analysis of century scale climate trends in the central highlands of Sri Lanka is presented. Monthly rainfall and temperature records of the period 1869-2006 from five climatological stations were analyzed. The trend is calculated by the least square regression analysis and the significance of the observed trend is estimated using the Mann-Kendall statistic. The results clearly show that there is a statistically significant decrease in annual rainfall in the western slopes of the central highlands. Throughout the last century, the annual reduction of rainfall in Nuwara Eliya which is at an altitude of $1895 \mathrm{~m}$ was $5.2 \mathrm{~mm} /$ year. The decrease is largely due to the reduction in southwest monsoon rainfall which contributes to $75 \%$ of the total reduction. No significant change was observed on the eastern side of the central highlands which receives rainfall predominantly from the northeast monsoons. The mean annual temperature in the mountainous region shows a uniform increasing trend which is in line with the 100-year global temperature increase of $0.8 \pm 0.2^{\circ} \mathrm{C}$. Kandy, which is at an altitude of $477 \mathrm{~m}$ and closely linked with the rainfall climatology of Nuwara Eliya, showed no significant change in the mean annual temperature. If the current trend continues, in another 100 years, western and eastern slopes of central highlands will receive the same amount of rainfall from the southwest monsoon and the northeast monsoon which will have far reaching consequences for Sri Lanka's economy and the ecology of the hill country.

\section{Introduction}

In recent years, a number of research studies have reported the variability and trends that have taken place in the global as well as regional level climate systems (IPCC 2007). While temperature has been increasing globally, rainfall is seen to fluctuate across regions. Global land precipitation has increased by a small amount (a trend of 0.9 $\mathrm{mm}$ /decade) during the last century with considerable variability in decadal scales (New et al. 2001). The dominant mode of inter-annual variability in land precipitation is linked to the El-Nino/ Southern Oscillation (ENSO) episode. Positive trends are found for annual precipitation in most parts of the world with some exceptions such as North Africa. An increase in rain intensities has been reported for selected countries in the northern and southern hemispheres covering $40 \%$ of the landmass, while the total number of rainy days has remained relatively stable (Groisman et al. 1999). In India, Sri Lanka's neighbour, evidence show that there is an increase in the frequency of extreme rainfall events during the last century, with increasing and decreasing trends in different regions (Roy and Balling 2004). Especially, the southwest monsoon rainfall has shown significant decreasing trends over a number of states including Kerala (Krishnakumar et al. 2009).

Keywords. Climate change; trend analysis; Mann-Kendall statistic; hill country; monsoons. 
There are several studies available in literature that discuss the short-term as well as long-term trends in annual and seasonal rainfall over Sri Lanka. A recent analysis carried out with long term (>100 years) rainfall time series revealed a fluctuation in seasonal rainfall in Sri Lanka (Malmgren et al. 2003). Statistically significant trends (both increasing and decreasing) related to the southwest monsoon season (May-September) were found to exist for some stations while no changes were seen for the northeast monsoon season (OctoberNovember). In general, loss of rainfall was found to be confined to the higher elevation areas. A study carried out with a relatively shorter (30 years) rainfall time series for the central mountainous region of Sri Lanka reported a decreasing trend in the region for annual rainfall while having increasing and decreasing trends for seasonal rainfall (Herath and Ratnayake 2004). The greatest decrease in rainfall was reported for the first inter-monsoon (March-April) period with increase in rain intensities and decrease in the number of rainy days. Another study carried out with long term (98-100 years) and short term (36-50 years) rainfall time series reported no coherent statistically significant increase or decrease in annual rainfall in the wet and dry zones over long periods, but a coherent decrease was reported for annual rainfall over short periods (Jayawardene et al. 2005). A study carried out to find the impact of climate change on the upper watersheds of the hill country reported a decline in annual rainfall on the western slopes of the highlands over long periods with the eastern side showing no such trends (Madduma Bandara and Wickremagamage 2004). The greatest decline was seen for the southwest monsoon period which accounts for a major share of rainfall in this region. A study carried out to find the impact of largescale deforestation on plantation agriculture in the hill country reported no uniformity in the trends of annual rainfall in the plantation areas (Wickramagamage 1998). This study also reported that the rainfall has declined significantly in few stations in the hill country. The links between climate variability and agricultural productivity, and the modulation of the rainfall over Sri Lanka by large scale oscillations such as Indian Ocean Dipole (IOD) have also been documented elsewhere (Panabokke and Walgama 1974; Yoshino and Suppiah 1983; Zubair 2002; Zubair et al. 2003; Malmgren et al. 2007; Jayawardene et al. 2015).

The above studies indicate that climate in the hill country of Sri Lanka has undergone changes during the last century and that there are differences in rainfall trends at regional levels. In the light of the earlier findings it is important to study the long term variation of monthly, seasonal and annual rainfall in high elevation areas to advance the existing knowledge further. In addition, intramonsoonal events such as wet and dry spells may indicate the changes to the climate of hill country that have taken place. This study focus on the climate change in the central highlands, particularly, on Nuwara Eliya where the greatest change in rainfall has been reported with a long period of data records available on rainfall and temperature. Since there was a suspicion that the observed changes are more widespread, data from four additional stations in the hill country from different elevations were also utilized in this study. The specific objectives of this study are to: determine the annual rainfall and temperature trends in the high elevation areas over long periods (>100 years); examine whether the observed changes are linked to monsoon seasons to corroborate with earlier findings; quantify the reduction or increase in seasonal rainfall; and study the changes in intra-monsoonal events such as wet and dry spells in central high lands.

\section{Methodology}

\subsection{Study area}

Sri Lanka has a tropical climate with mean annual air temperature ranging from a low of $15^{\circ} \mathrm{C}$ in high altitudes to a high of $28^{\circ} \mathrm{C}$ in low altitudes. The diurnal variation of temperature is high in mountainous regions in comparison to the coastal regions. The variability in mean monthly temperature is $\pm 3^{\circ} \mathrm{C}$ in high altitudes while the variability in mean monthly temperature is $\pm 1^{\circ} \mathrm{C}$ in low altitudes. The minimum and maximum mean temperatures are observed in the months of January and May, respectively. The rainfall pattern of the island is essentially governed by two monsoons, the southwest monsoon from May to September and the northeast monsoon from December to February. The transition period between the two monsoons is defined by the first inter-monsoon from March to April and the second inter-monsoon from October to November.

The country is divided according to the temporal and spatial variations of rainfall into two distinct zones, the dry zone and the wet zone (Domroes and Ranatunge 1993). In general, the wet zone receives rainfall throughout the year while the dry zone experiences long dry periods. Much of the rain in the dry zone falls during the months from October to February. The hill country is located in the wet zone and is commonly defined as an area receiving more than $1900 \mathrm{~mm}$ of annual rainfall. The higher elevation areas of the hill country receive as much as $4000 \mathrm{~mm}$ of annual rainfall. The elevation of the highlands ranges from about 300 to $2500 \mathrm{~m}$ (Pidurutalaga is the highest at $2524 \mathrm{~m}$ ). 
This study focuses mainly on Nuwara Eliya which is situated in the central highlands at an altitude of $1895 \mathrm{~m}$. The mean annual rainfall in Nuwara Eliya is $2161 \mathrm{~mm}$ and the mean temperature is $15^{\circ} \mathrm{C}$. Four stations around Nuwara Eliya which are situated in the periphery of the central highlands, namely, Kandy, Badulla, Diyathalawa, and Ratnapura were also selected for the study. Kandy is situated in the northwestern part of the central highlands whereas Ratnapura is situated in the lowlands towards the southwest of the highlands. Badulla and Diyathalawa are situated in the Uva basin in the eastern and south-eastern sides of the central highlands. Nuwara Eliya, Kandy and Ratnapura receive rain predominantly from the southwest monsoon, Badulla from the northeast monsoon and Diyathalawa from the second inter-monsoon. Figure 1 shows the locations of the selected stations.

For the present study, monthly rainfall and air temperature records for the selected stations were extracted from the published data records of Yoshino and Suppiah (1982). The recent data records (after 1980) were directly obtained from

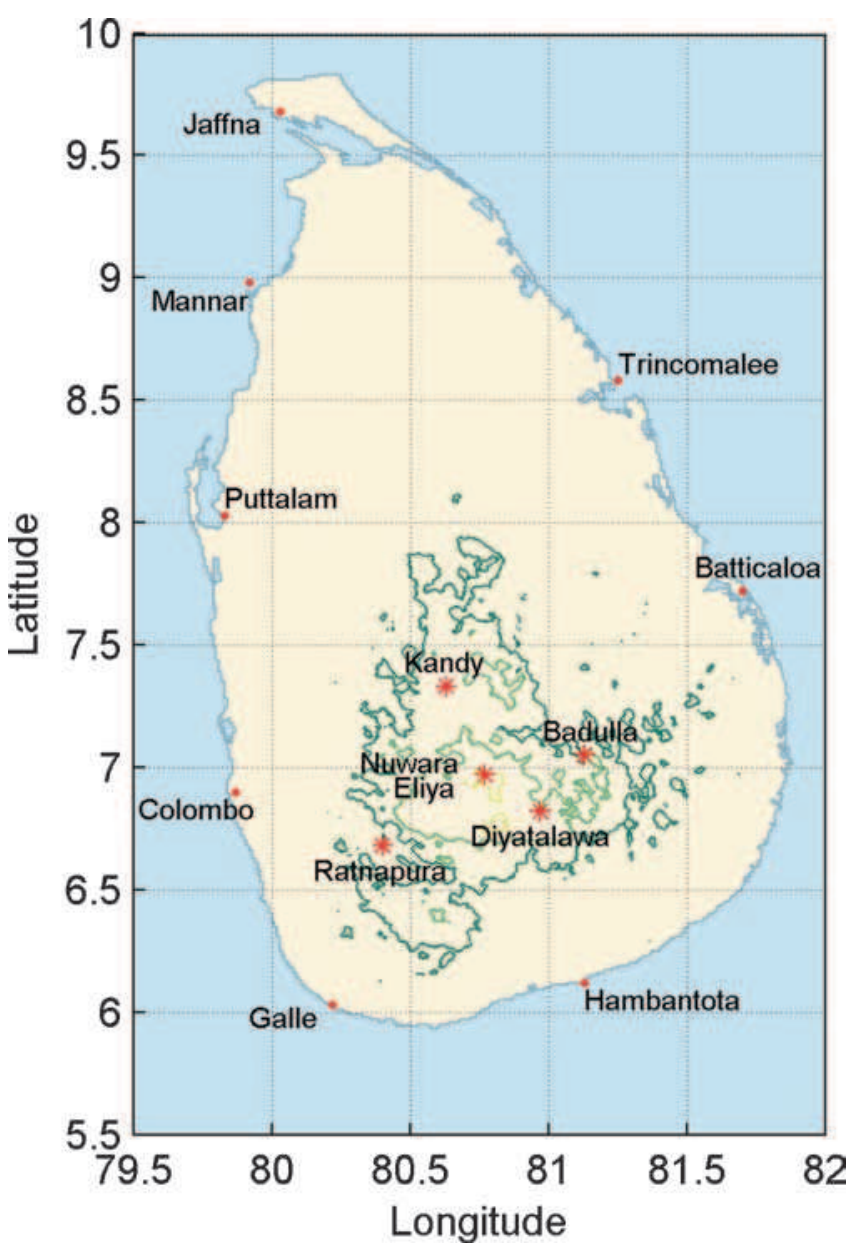

Figure 1. A map showing the locations of the selected stations in the central highlands of Sri Lanka. the Department of Meteorology, Sri Lanka. The analysis in this study is based on monthly rainfall and temperature data of the period 1869-2006. For Diyathalawa, data is only available from 1901 and hence, had a shorter time series than the other four stations. For further analysis, monthly data has been categorized according to the timing of the monsoons; i.e., five months for the southwest monsoon, three months for the northeast monsoon, two months each for the first and the second intermonsoons. The lengths of the data records together with the relevant station information (latitude, longitude and altitude) are given in table 1 .

\subsection{Trend detection}

First, annual and seasonal rainfall and temperature time series were computed for each station. The trend was estimated for each station using a least square regression analysis. Temporal changes in the annual and seasonal values were also analyzed by the Mann-Kendall test to confirm the significance of the test.

The Mann-Kendall test is based on the test statistic $S$ calculated using the formula (Yue et al. 2002)

$$
S=\sum_{k=1}^{n-1} \sum_{j=k+1}^{n} \operatorname{sgn}\left(x_{j}-x_{k}\right)
$$

where $x_{j}, x_{k}$ are the sequential data values, $n$ is the length of the dataset, and

$$
\operatorname{sgn}\left(x_{j}-x_{k}\right)=\left\{\begin{aligned}
+1 & \text { if } x_{j}-x_{k}>0 \\
0 & \text { if } x_{j}-x_{k}=0 \\
-1 & \text { if } x_{j}-x_{k}<0
\end{aligned}\right.
$$

When $n$ is large, the statistic $S$ is approximately normally distributed with a zero mean and a variance defined by:

$$
\sigma^{2}(S)=\frac{1}{18}\left[n(n-1)(2 n+5)-\sum_{p=1}^{q} t_{p}\left(t_{p}-1\right)\left(2 t_{p}+5\right)\right]
$$

where $t_{p}$ is the number of ties for the $p$ th value and $q$ is the number of tied values.

The standardized test statistic $Z$ is computed by:

$$
Z=\left\{\begin{array}{cl}
\frac{S-1}{\sigma(S)} & \text { if } S>0 \\
0 & \text { if } S=0 \\
\frac{S+1}{\sigma(S)} & \text { if } S<0
\end{array}\right.
$$

The statistic $Z$ follows the standard normal distribution with mean zero and variance one. A positive value of $Z$ indicates an increasing trend while a negative value indicates a decreasing trend. A significance level of $0.05(Z=1.96)$ was considered as satisfactory for this study. 
Table 1. Details of the rainfall stations selected for the study.

\begin{tabular}{lcccccc}
\hline Station & $\begin{array}{c}\text { Latitude } \\
\left({ }^{\circ} \mathrm{N}\right)\end{array}$ & $\begin{array}{c}\text { Longitude } \\
\left({ }^{\circ} \mathrm{E}\right)\end{array}$ & $\begin{array}{c}\text { Altitude } \\
(\mathrm{m})\end{array}$ & $\begin{array}{c}\text { Rainfall } \\
(\mathrm{mm})\end{array}$ & Time span & $\begin{array}{r}\text { Period } \\
(\text { years })\end{array}$ \\
\hline Badulla & 7.05 & 81.13 & 670 & 1816 & $1869-2006$ & 138 \\
Diyathalawa & 6.82 & 80.97 & 1248 & 1629 & $1901-2006$ & 106 \\
Kandy & 7.33 & 80.63 & 477 & 2028 & $1870-2006$ & 137 \\
Nuwara Eliya & 6.97 & 80.77 & 1895 & 2161 & $1869-2006$ & 138 \\
Ratnapura & 6.68 & 80.40 & 34 & 3826 & $1869-2006$ & 138 \\
\hline
\end{tabular}

Table 2. Results of the least square regression analysis and the $M K$ statistic for the annual rainfall and annual mean temperature time series for the selected weather stations.

\begin{tabular}{lccccc}
\hline & \multicolumn{2}{c}{ Annual rainfall } & & \multicolumn{2}{c}{ Mean annual temperature } \\
\cline { 2 - 3 } \cline { 5 - 6 } Station & $\begin{array}{c}\text { Trend } \\
\text { (mm/year })\end{array}$ & MK statistics & $\begin{array}{c}\text { Trend } \\
\left({ }^{\circ} \mathrm{C} / \text { year }\right)\end{array}$ & MK statistics \\
\hline Badulla & -1.905 & -1.82 & & +0.008 & $+7.66 *$ \\
Diyathalawa & -0.673 & -0.84 & & +0.008 & $+4.63 *$ \\
Kandy & -2.868 & $-3.72 *$ & & +0.001 & +0.72 \\
Nuwara Eliya & -5.153 & $-6.10 *$ & & +0.011 & $+10.6 *$ \\
Ratnapura & -0.658 & -0.71 & & +0.005 & $+6.30 *$ \\
\hline
\end{tabular}

*Significant at 0.05 level.

\section{Results and discussion}

\subsection{Annual trends}

The linear trend calculated through the least square regression analysis and the Mann-Kendall statistic for the annual rainfall and annual mean temperature time series are presented in table 2 . Asterisks indicate the trends that are significant at $95 \%$ confidence level confirmed by the MannKendall test statistic. The annual rainfall time series shows a decreasing trend for all stations. For Kandy and Nuwara Eliya, the observed trends are significant at 0.05 level while for Badulla, the trend is significant only at 0.1 level. There is no significant trend in Diyathalawa or Ratnapura. Earlier study (Madduma Bandara and Wickremagamage 2004) reported that at stations located in the periphery of the mountain mass such as Kandy, Badulla and Ratnapura, trends are not statistically significant. Further analysis showed that this difference is caused by the length of the data used. The available data from 1870-1899 was not utilized in the earlier study.

The annual mean temperature time series show an increasing trend in temperature for all stations. Badulla, Diyathalawa, Nuwara Eliya and Ratnapura showed trends significant at 0.05 level, while Kandy showed no significant trend in the mean annual temperature time series. The highest trend was observed at Nuwara Eliya. Although not conclusive, as suggested in a previous study (Wickramagamage 1998), the general pattern seems to indicate that the rate of change of temperature is higher at high elevation areas.
The least square regression results for Nuwara Eliya which has shown the greatest reduction in rainfall is shown in figure 2(a). During the last century, the annual rainfall in Nuwara Eliya has reduced by $515 \mathrm{~mm}$ which is approximately $25 \%$ of the rainfall it receives annually. Although year-toyear variability is present in the data, the decreasing trend in rainfall is steady and absent of significant deviations from the general trend line. Kandy which shows the second greatest reduction in annual rainfall among the selected stations shows a reduction of $287 \mathrm{~mm}$ of rainfall during the last century. This corresponds to approximately $15 \%$ of the annual rainfall it receives.

When the correlations between the seasonal rainfall of Nuwara Eliya and the other four stations were studied, it was found that, between Nuwara Eliya and Kandy, the southwest monsoon, northeast monsoon and the second inter-monsoon rainfall are strongly correlated $(r \geq 0.7)$. The northeast monsoon rainfall in Nuwara Eliya and the three other stations, namely, Kandy, Badulla and Diyathalawa are also strongly correlated. The highest correlation was seen for the northeast monsoon with a correlation coefficient of 0.87 between Nuwara Eliya and Diyathalawa. No significant correlation was observed between Ratnapura and Nuwara Eliya during any of the seasons $(r \leq 0.5)$. The first inter-monsoon rainfall in Nuwara Eliya showed a moderate correlation with the rainfall in Diyathalawa and Badulla. In figure 2(b), the correlation between the seasonal rainfall observed in Nuwara Eliya and Kandy is shown for the southwest monsoon $(r=0.75)$, the northeast monsoon $(r=0.78)$ and the second inter-monsoon $(r=0.73)$. 


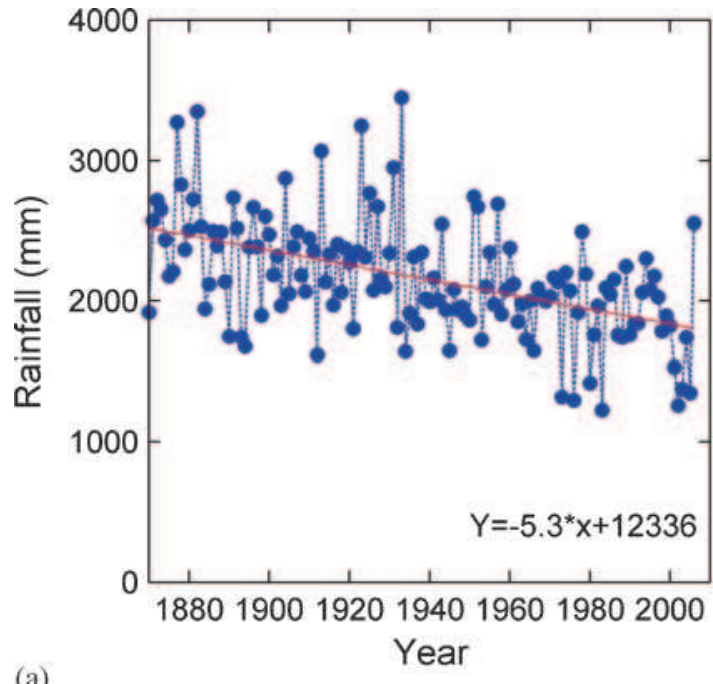

(a)

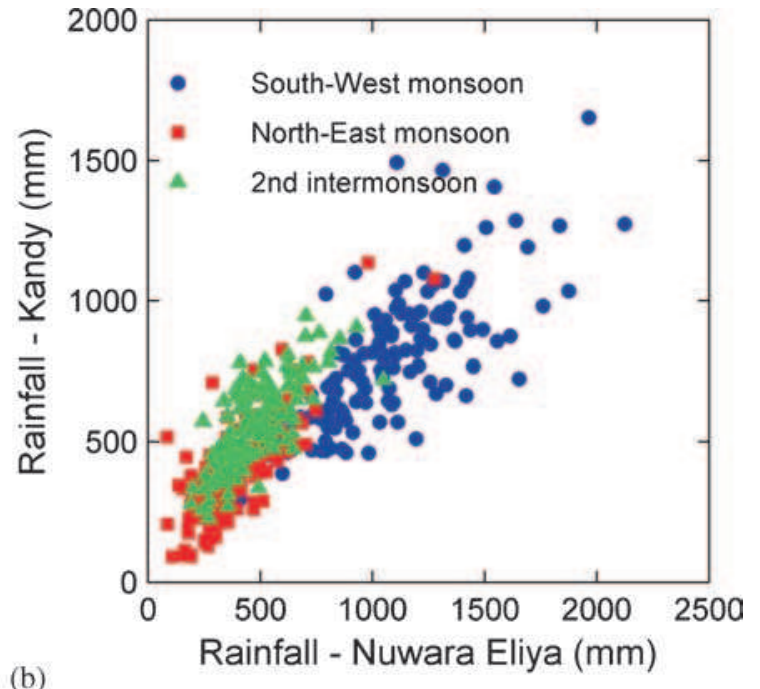

(b)

Figure 2. (a) Trend in the annual rainfall time series for Nuwara Eliya. The dashed line indicates the best fit linear regression line for the data. (b) Correlation between seasonal rainfall in Nuwara Eliya and Kandy for the southwest monsoon (circles), northeast monsoon (squares) and second inter-monsoon (triangles).

This observation is consistent with the findings from another study (Malmgren et al. 2007) where precipitation zones are identified based on similar rainfall fluctuation patterns. The study shows that during the southwest monsoon months, Nuwara Eliya and Kandy, and, Badulla and Diyatalawa can be classified into two meso-scale zones with different rainfall characteristics. During the northeast monsoon and first inter-monsoon months, all four stations show similar characteristics. During the second inter-monsoon months, Nuwara Eliya and Kandy show similar characteristics. During all seasons, Ratnapura has been classified as a separate zone having different characteristics compared to Nuwara Eliya.

In figure $3(\mathrm{a})$, the regression results for the mean annual temperature of Ratnapura, Badulla, Diyathalawa, and Nuwara Eliya are shown. In general, all stations show a similar increasing trend which agrees with the reported 100-year global temperature increase of $0.8 \pm 0.2^{\circ} \mathrm{C}$, with Nuwara Eliya showing the highest trend of $1.1^{\circ} \mathrm{C}$. Kandy, which had a seasonal rainfall was correlated with that of Nuwara Eliya, showed no connection with temperature trends seen at other stations. In fact, the mean annual temperature in Kandy has not been changed significantly during the last century $\left(24.7 \pm 0.4^{\circ} \mathrm{C}\right)$. It is possible that local factors such as land use and population may contribute to overshadowing some of the global effects.

When the correlations between the mean seasonal temperature between Nuwara Eliya and the other four stations were studied, it was found that the correlation is quite poor between Nuwara Eliya and Kandy for all seasons. The result was the same when this was extended to study mean monthly temperature values. The highest correlation was seen for the month of July which was still weak $(r=0.47)$. However, it was noted that the long term mean monthly temperature values between the two stations follow a cyclic pattern. This is shown in figure 3(b). The error bars represent the error of the long term mean monthly temperature; i.e., $\sigma / \sqrt{ } n$ where $\sigma$ is the standard deviation and $n$ is the series length. The connecting line is drawn to indicate how the long term mean monthly temperature values change within a year (from January to December). January is the coldest month for both stations while May is the hottest month for Nuwara Eliya and April for Kandy. The variation of annual cycle of mean monthly temperature of the two locations which are situated at two different elevations is much more complex than a simple linear relationship. The highest seasonal temperature correlation was seen between Nuwara Eliya and Diyathalawa for the southwest monsoon season $(r=0.64)$ and the northeast monsoon season $(r=0.73)$ which are situated at high elevations.

\subsection{Seasonal trends}

In order to study whether the reduction in annual rainfall is linked to any of the monsoons, a least square regression and Mann-Kendall statistic were computed separately for all four seasons. The results of this analysis for each station are presented in table 3 for the southwest and the northeast monsoon seasons.

During the southwest monsoon, the seasonal rainfall time series show a decreasing trend for all stations except Diyathalawa. For Kandy and 


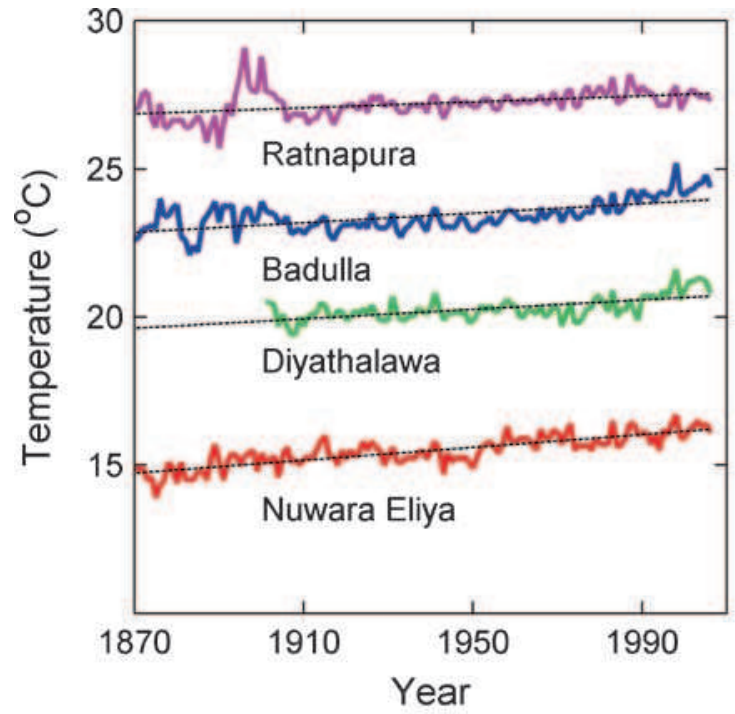

(a)

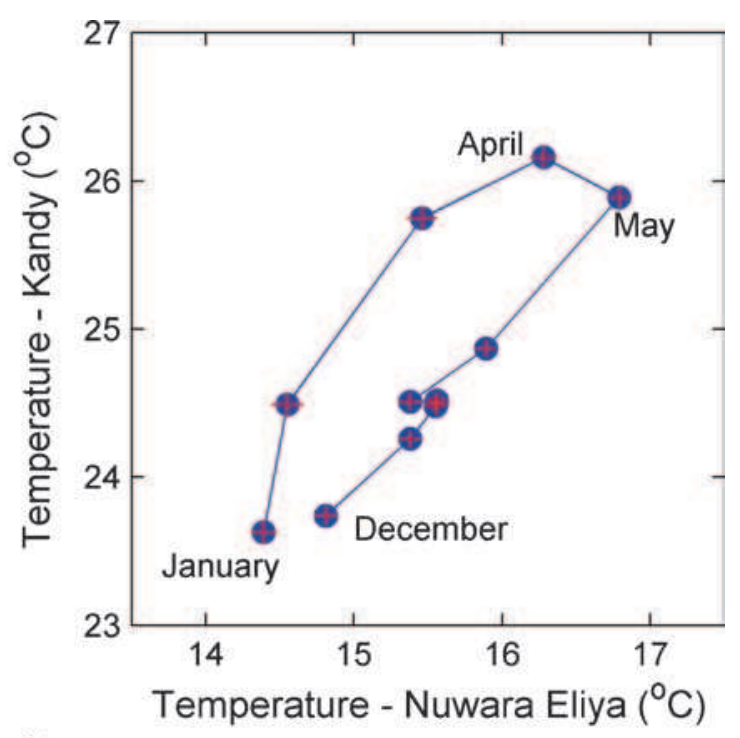

(b)

Figure 3. (a) Mean temperature trends which are consistent with the global temperature changes. (b) Correlation between long term mean monthly temperature in Nuwara Eliya and Kandy. Error bars indicate the error of the long term mean monthly temperature variation in the full dataset. The connecting line is drawn to indicate how temperature changes between months.

Table 3. Southwest and northeast monsoon seasonal rainfall and temperature trends.

\begin{tabular}{|c|c|c|c|c|}
\hline \multirow[b]{2}{*}{ Station } & \multicolumn{2}{|c|}{ Seasonal rainfall } & \multicolumn{2}{|c|}{ Mean seasonal temperature } \\
\hline & $\begin{array}{c}\text { Trend } \\
(\mathrm{mm} / \text { year })\end{array}$ & MK statistics & $\begin{array}{c}\text { Trend } \\
\left({ }^{\circ} \mathrm{C} / \text { year }\right)\end{array}$ & MK statistics \\
\hline \multicolumn{5}{|c|}{ Southwest monsoon } \\
\hline Badulla & -0.212 & -0.71 & +0.010 & $+8.45 *$ \\
\hline Diyathalawa & +0.268 & +0.79 & +0.008 & $+3.32 *$ \\
\hline Kandy & -2.222 & $-4.32 *$ & +0.001 & +0.74 \\
\hline Nuwara Eliya & -3.891 & $-5.77 *$ & +0.009 & $+9.01 *$ \\
\hline Ratnapura & -1.362 & -1.51 & +0.004 & $+4.62 *$ \\
\hline \multicolumn{5}{|c|}{ Northeast monsoon } \\
\hline Badulla & -1.012 & -1.11 & +0.006 & $+4.31 *$ \\
\hline Diyathalawa & -0.775 & -1.48 & +0.008 & $+4.27 *$ \\
\hline Kandy & -0.574 & -1.54 & +0.000 & +0.34 \\
\hline Nuwara Eliya & -0.477 & -1.25 & +0.012 & $+8.65 *$ \\
\hline Ratnapura & +0.497 & +0.48 & +0.007 & $+6.39 *$ \\
\hline
\end{tabular}

*Significant at 0.05 level.

Nuwara Eliya, the decreasing trend is significant at 0.05 level. Statistically significant trends were seen in the mean temperature time series for Badulla, Diyathalawa, Ratnapura and Nuwara Eliya. The observed seasonal trend patterns for the southwest monsoon season are very similar to the patterns observed for the annual time series.

When the northeast seasonal rainfall time series was analyzed, a contrasting pattern to the one of the southwest monsoon season was observed. Ratnapura showed a positive trend while all other stations showed negative trends. None of the stations were significant even at 0.1 level. When two inter-monsoon seasonal rainfall time series were analyzed, a pattern very similar to that of the northeast monsoon season was observed. Therefore, it can be concluded that decreasing trends observed in the annual rainfall are mainly caused by the decrease in the southwest monsoon rainfall. When the mean temperature time series for the northeast monsoon season as well as for the two inter-monsoon seasons were studied, it was found that the behaviour of the mean temperature time series was similar for all three seasons. For all seasons, Badulla, Diyathalawa, Ratnapura and Nuwara Eliya showed statistically significant increasing trends at 0.05 level. In contrast, Kandy showed no significant change in mean seasonal temperature over the last 137 years. 


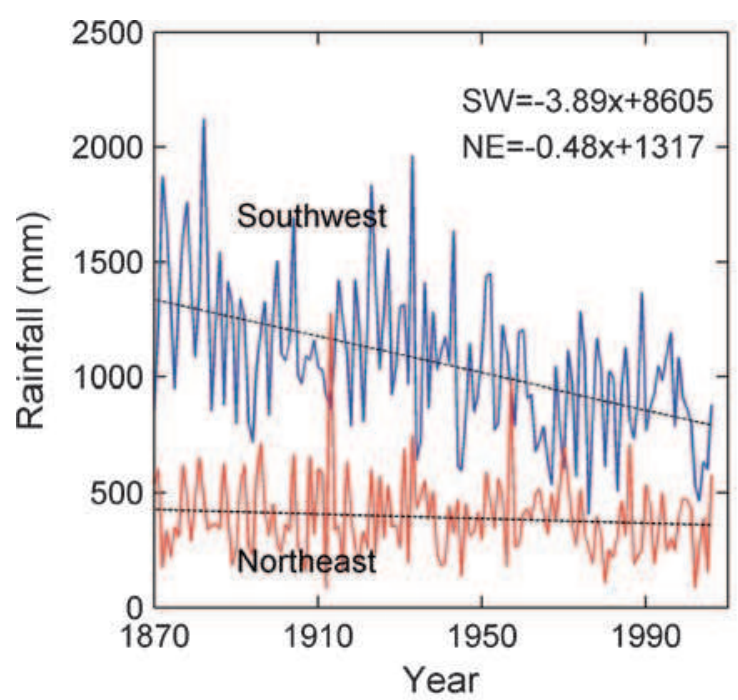

(a)

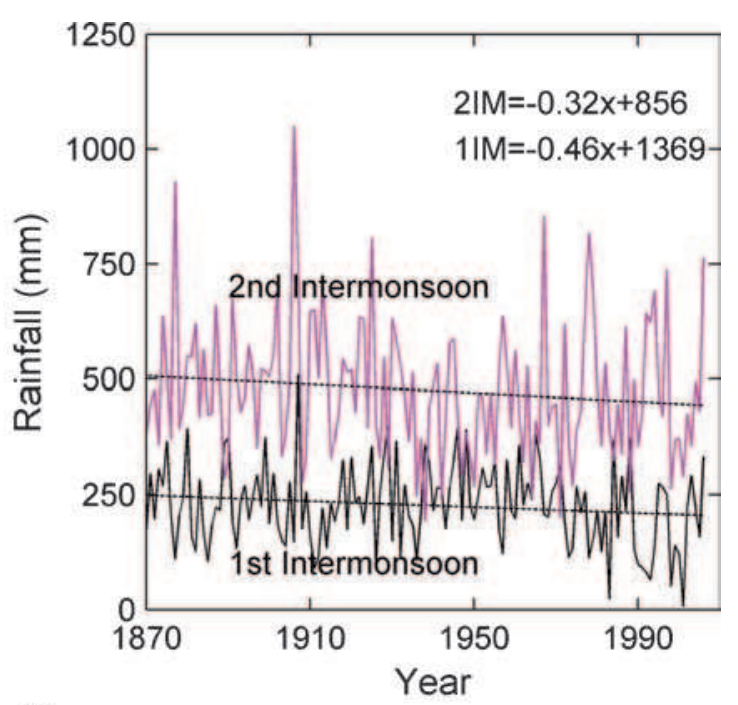

(b)

Figure 4. Trends in the seasonal rainfall time series for Nuwara Eliya (a) southwest and northeast monsoons and (b) first and second inter-monsoon. There is a significantly high decline in rainfall for the southwest monsoon season.

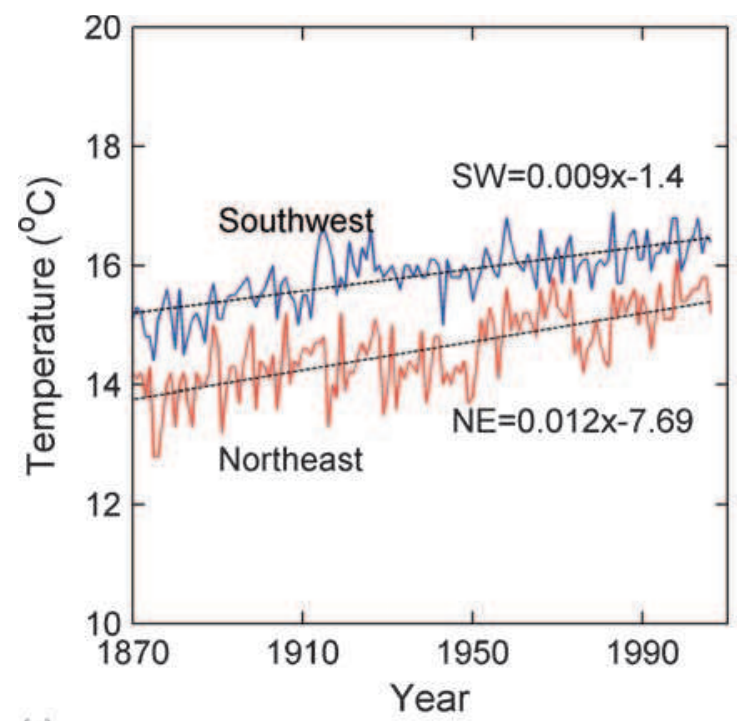

(a)

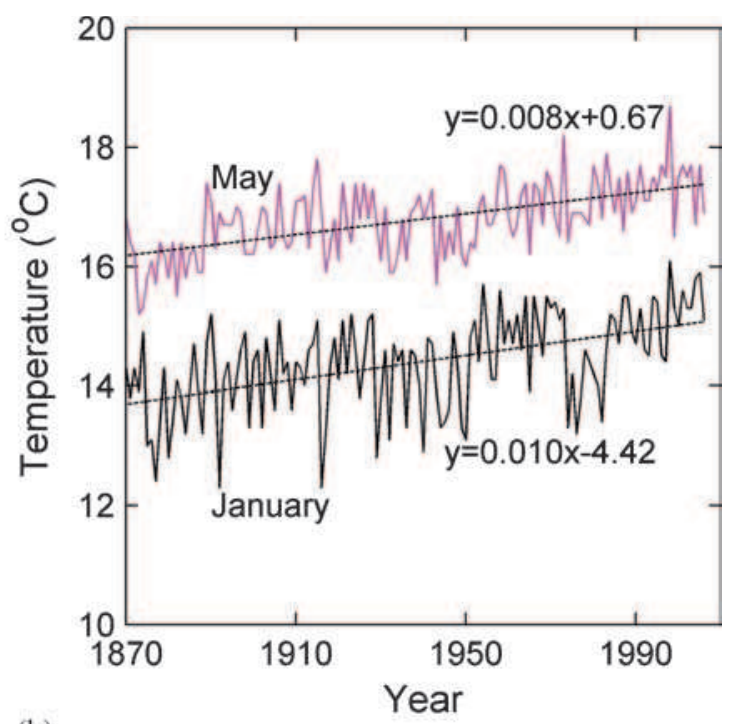

(b)

Figure 5. Trend in the mean temperature time series for Nuwara Eliya (a) southwest and northeast monsoons and (b) hot (May) and cold (January) months.

Figure 4 shows the seasonal rainfall time series for Nuwara Eliya. The reduction in rainfall during the northeast monsoon and the first and second inter-monsoon is quite small and at a level of $0.3-$ $0.5 \mathrm{~mm} /$ year which was found to be not significant by the Mann-Kendall statistic. For the southwest monsoon, the decrease is extremely high and at a level of $3.9 \mathrm{~mm} /$ year. This accounts for over $75 \%$ in the reduction of the annual rainfall at Nuwara Eliya. Similarly, for Kandy, the reduction in annual rainfall due to the reduction in the southwest monsoon rainfall is $77 \%$. Thus, the decline of the southwest monsoon rainfall is the major contributor to the century-scale reduction in annual rainfall in the central highlands of Sri Lanka.

In figure $5(\mathrm{a})$, the mean temperature trends are shown for the southwest and northeast monsoon periods for Nuwara Eliya. Although not shown here, a similar behaviour is observed for the two inter-monsoon periods too. In figure 5(b), the same is shown for the coldest (January) month and the hottest (May) month. It can be seen that the trends are quite uniform and on average consistent with the global change of $0.008^{\circ} \mathrm{C} /$ year. A closer inspection showed a slightly higher increase in the trend for the coldest months (northeast monsoon period) 


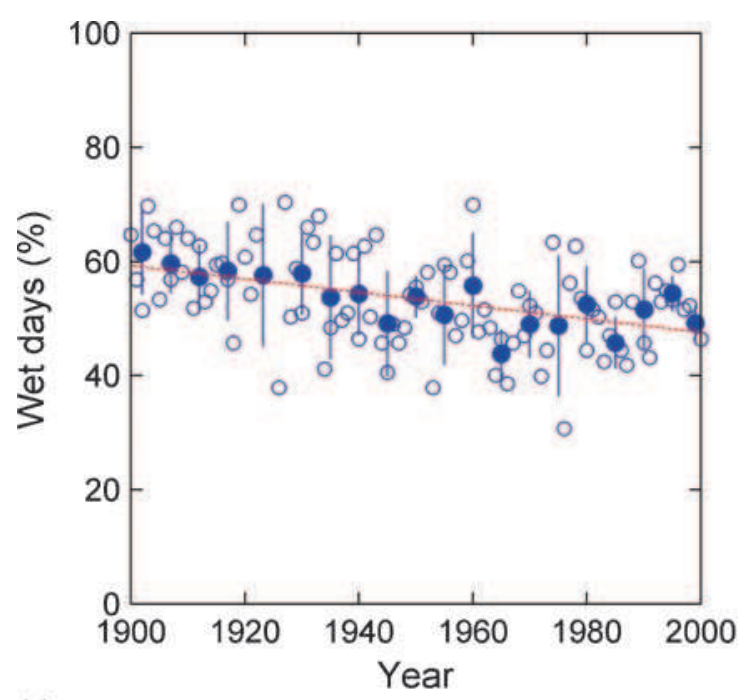

(a)

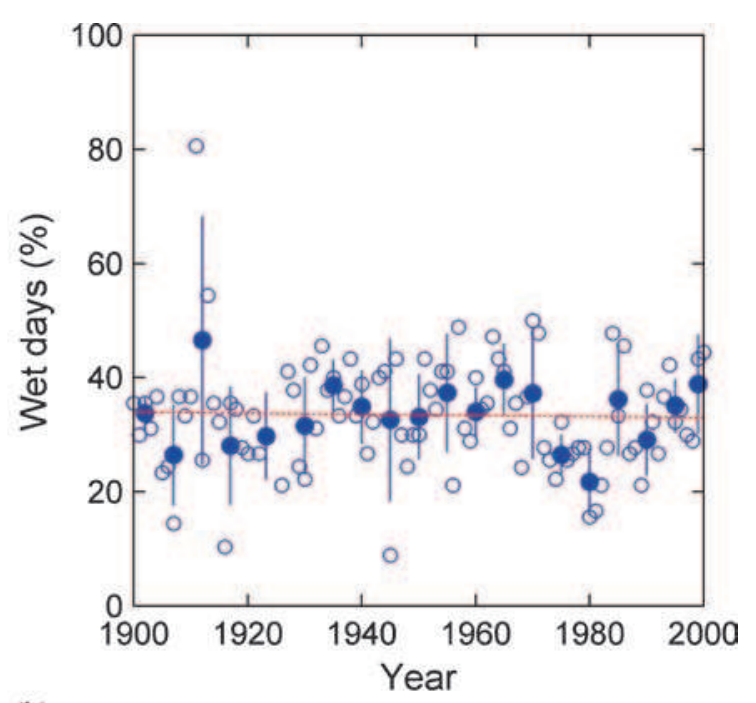

(b)

Figure 6. Percentage of wet days observed during (a) southwest monsoon season and (b) northeast monsoon season. Open circles indicate the estimates for each year. Closed circles with error bars are calculated for 5-year time segments. Dashed lines are the best fit to the data.

than for the hottest months (southwest monsoon period). As a percentage, during the last century, in Nuwara Eliya, the mean temperature has increased during the hottest and coldest months by $7 \%$ and $10 \%$ respectively, i.e., the difference in temperature between the hottest and coldest months is narrowing in Nuwara Eliya. Further studies may indicate whether this change is reflected in the decline of the diurnal temperature range in Nuwara Eliya.

\subsection{Change of climate}

A change in climate is expected to change the rainfall characteristics. Thus, the declining rainfall in Nuwara Eliya was studied in terms of the occurrence of wet and dry days/spells. In order to calculate wet and dry days, it was necessary to specify a threshold to identify a day as being wet or dry. The measurements were available up to $0.1 \mathrm{~mm}$ level. At this level, rainfall can evaporate easily. Thus, in this work, a wet day was defined as a day with the total rainfall exceeding $1.0 \mathrm{~mm}$ and a dry day was defined as a day with the total rainfall lower than $1.0 \mathrm{~mm}$. To reduce variations due to missing data, wet days were calculated as a percentage to the total number of days where the measurements were taken excluding missing data. Therefore, for southwest and northeast monsoons, if there are no missing data, daily rainfall measurements should be available for 153 and 90 days, respectively. The analysis was carried out with daily rainfall measurements taken from 1900 to 2000. Results of this analysis are shown in figure $6(\mathrm{a}$ and $\mathrm{b})$. The points with the error bars indicate the mean values for 5-year time bands with the standard deviation. The dotted line is the best fit to the data. There is a clear decline in the percentage of wet days during last 101 years in the southwest monsoon season. The percentage of wet days has decreased from $59 \%$ to $47 \%$. There is no significant change in the number of wet days during the northeast monsoon season $(\sim 1 \%)$. Annual variability of percentage of wet days is high for both seasons.

In order to investigate whether there are changes in the depth and duration of southwest monsoon rainfall, the rain per rainy day and length of wet spells were computed. The rain per rainy day was defined as the average rainfall measured on wet days and the length of wet spells were defined as the consecutive number of days with daily rainfall exceeding $1.0 \mathrm{~mm}$ threshold. Since daily rainfall measurements were used in the analysis, the minimum length of wet spell was taken as 1 day. Result of this analysis is shown in figure 7(a and b) for southwest monsoon season. The data show that the rain per rainy day during southwest monsoon season is $12 \pm 2 \mathrm{~mm}$ which has not changed during last 100 years. However, there is a clear decline of length of wet spells. The length of wet spells has changed from 4.6 to 3.1 days. Although there is no change in rain per rainy day, due to substantial decline in length of wet spells (or the percentage of wet days), the amount of rainfall has declined steadily during the southwest monsoon season. Since southwest monsoon rainfall contribute to $40 \%-50 \%$ of the total annual rainfall received by the central highlands, the steady decline in the southwest monsoon rainfall will certainly have 


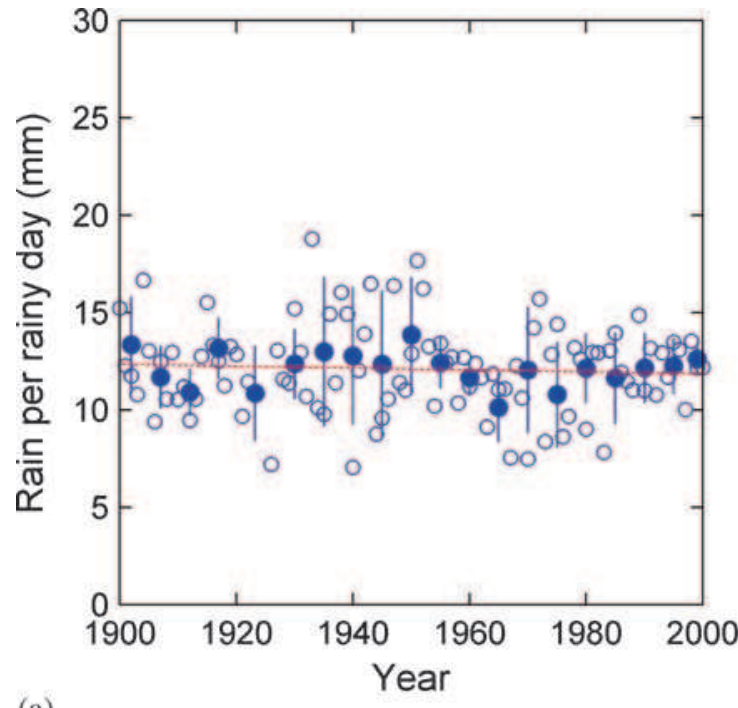

(a)

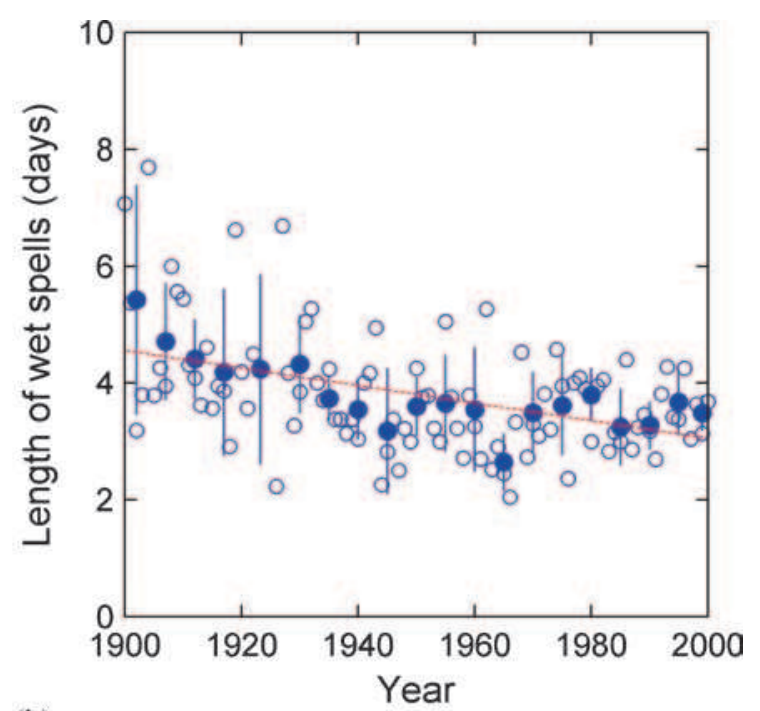

(b)

Figure 7. (a) Rain per rainy day for southwest monsoon season. (b) Length of wet spells for southwest monsoon season. Open circles indicate the estimates for each year. Closed circles with error bars are calculated for 5-year time segments. Dashed lines are the best fit to the data.

implications on the economy due to adverse effect on crop cultivation and hydro-power generation.

\section{Conclusions}

Century scale variability and trend of rainfall and temperature in the mountainous region of Sri Lanka is presented. Nuwara Eliya which is situated at an altitude of $1895 \mathrm{~m}$ shows a marked decline in annual rainfall whereas the mean annual temperature increase is consistent with the global temperature increase. The southwest monsoon's dominance as the main rainfall provider to this region is slowly changing due to its gradual decrease over time. If the current trend continues, in another 100 years, Nuwara Eliya will receive the same amount of rainfall from the southwest monsoon as from the northeast monsoon which will have far reaching consequences for Sri Lanka's economy and the ecology of the hill country.

The steady decline in annual rainfall during the southwest monsoon season in the central mountainous region can be attributed to the decrease in the length of wet spells (while having no change in rain per rainy day). The rainfall in this region contributes to Randenigala, the largest reservoir constructed under the Accelerated Mahaweli Development Program for hydro-power generation and release water, especially to the Mahaweli A, B and $\mathrm{C}$ zones in the dry zone for agriculture purposes. A reduction in rainfall in this region would affect hydro-power generation and the agriculture industry. Furthermore, since tea production is affected by dry spells and droughts (Madduma Bandara and Wickremagamage 2004), the export market for crops such as tea, where Sri Lanka is ranked the third largest producer, would be affected by the decline in length of wet spells in the hill country.

It has been suggested that the monsoon systems affecting the country are interrelated to the climatic signals associated with the El Nino/Southern Oscillation episode (Zubair 2002; Malmgren et al. 2007). Although all stations in the hill country are not affected to the same level, this study as well as some of the earlier findings indicate that there are global effects which influence the monsoon rainfall which is affecting the high elevation areas. The hill country contributes immensely towards hydropower generation and irrigation. Thus, with the existing evidence, effective management of available local water resources and mitigation measures are of paramount importance for the central highlands of Sri Lanka.

\section{Acknowledgement}

This work was supported by the National Research Council, Sri Lanka under research grant number NRC 06-18.

\section{References}

Domroes M and Ranatunge E 1993 A statistical approach towards a regionalization of daily rainfall in Sri Lanka; Int. J. Climatol. 13 741-754, doi: 10.1002/joc.3370130704.

Groisman P Y et al. 1999 Changes in the probability of heavy precipitation: Important indicators of climate change; Climate Change 42 243-283, doi: 10.1023/A:10054328031880. 
Herath S and Ratnayake U 2004 Monitoring rainfall trends to predict adverse impacts - A case study from Sri Lanka (1964-1993); Global Environ. Change 14 71-79, doi: 10.1016/j.gloenvcha.2003.11.009.

IPCC 2007 Technical Summar; In: Climate Change 200\%: The Physical Science Basis, Cambridge University Press, Cambridge.

Jayawardene H K W I, Sonnadara D U J and Jayewardene D R 2005 Trends of rainfall in Sri Lanka over the last century; Sri Lankan J. Phys. 6 7-17.

Jayawardene H K W I, Jayewardene D R and Sonnadara D U J 2015 Interannual variability of precipitation in Sri Lanka; J. Nat. Sci. Foundation Sri Lanka 43(1) 75-82, doi: 10.4038/jnsfsr.v43i1.7917.

Krishnakumar K N, Prasada Rao G S L H V and Gopakumar C S 2009 Rainfall trends in twentieth century over Kerala, India; Atmos. Environ 43 1940-1944, doi: 10.1016/j.atmosenv.2008.12.053.

Madduma Bandara C M and Wickremagamage P 2004 Climate change and its impact on upper watersheds of the hill country of Sri Lanka; Proceedings of the International Conference on Sustainable Water Resources Management in Changing Environment of the Monsoon Region, Colombo, Sri Lanka, pp. 94-109.

Malmgren B A, Hulugalla R, Hayashi Y and Mikami T 2003 Precipitation trends in Sri Lanka since the 1870s and relationships to El Niño-southern oscillation; Int. J. Climatol. 23 235-1252, doi: 10.1002/joc.921.

Malmgren B A, Hulugalla R, Lindeberg G, Inoue Y, Hayashi $\mathrm{Y}$ and Mikami T 2007 Oscillatory behaviour of monsson rainfall over Sri Lanka during the late 19th and 20th centuries and its relationship to SSTs in the Indian Ocean and ENSO; Theoret. Appl. Climatol. 89 115-125, doi: 10.1007/s00704-006-0225-9.

New M, Todd M, Hulme M and Jones P 2001 Precipitation measurements and trends in the twentieth century; Int. J. Climatol. 21 1899-1922, doi: 10.1002/joc.680.

Panabokke C R and Walgama A 1974 The application of precipitation confidence limits to crop water requirements in dry zone agriculture in Sri Lanka; J. Nat. Sci. Council of Sri Lanka 2 95-113.

Roy S S and Balling R C 2004 Trends in extreme daily precipitation indices in India; Int. J. Climatol 24 457-466, doi: $10.1002 /$ joc.995.

Yoshino M M and Suppiah R 1982 Climatic records of monsoon Asia; Climatological Notes, Tskuba, Japan 31 $1-80$.

Yoshino M M and Suppiah R 1983 Climate and paddy production: A study on selective districts in Sri Lanka; Climatological Notes, Tsukuba, Japan 33 33-50.

Yue S, Pilon P and Cavadias G 2002 Power of the MannKendall and Spearman's rho tests for detecting monotonic trends in hydrological series; J. Hydrol 259 254-271, doi: 10.1016/S0022-1694(01)00594-7.

Wickramagamage P 1998 Large-scale deforestation for plantation agriculture in the hill country of Sri Lanka and its impacts; Hydrol. Process. 12 2015-2028, doi: 10.1002/(SICI)1099-1085(19981030)12:13/14.

Zubair L 2002 El Nino-Southern Oscillation influences on rice production in Sri Lanka; Int. J. Climatol. 22249 260, doi: $10.1002 /$ joc.714.

Zubair L, Rao S A and Yamagata T 2003 Modulation of Sri Lankan Maha rainfall by the Indian Ocean Dipole; Geophys. Res. Lett. 30(2) 1063, doi: 10.1029/2002GL015639. 